\title{
Spiritual Well-Being and Its Role on the Sociality of Selected Catholic Religious Novices
}

\author{
Fides del Castillo ${ }^{1, *}$, Clarence Darro del Castillo ${ }^{2}$ and Maricris Alvarez ${ }^{3}$ \\ 1 Theology and Religious Education Department, De La Salle University, Manila 1004, Philippines \\ 2 Lumina Foundation for Integral Human Development, Calamba City 4027, Philippines; \\ cdbdelcastillo@gmail.com \\ 3 Parochial Handmaids of the Holy Spirit, Cavite 4118, Philippines; maricris_alvarez@dlsu.edu.ph \\ * Correspondence: fides.delcastillo@dlsu.edu.ph
}

Received: 23 June 2020; Accepted: 16 July 2020; Published: 20 July 2020

check for updates

\begin{abstract}
Religion and spirituality are difficult to define and elusive to capture by standard scientific methods. Despite these challenges, the researchers aim to contribute to the growing body of knowledge on the psychology of religion by investigating the religious experience of Catholic novices and their spiritual well-being. Using the Spiritual Health and Life-Orientation Measure (SHALOM) developed by John Fisher, objective data was gathered from selected individuals going through religious formation. The aim was to determine the spiritual well-being of Catholic religious novices and its implication to their sociality. The results show that there was a significant difference in the quality of relationships of each novice with themselves, other people, the environment and God. Thus, there is dissonance between the ideals of the persons in the novitiate and their lived experience.
\end{abstract}

Keywords: spiritual well-being; spiritual experiences; youth; spirituality; religious experiences; catholic religious novices; religious formation

\section{Introduction}

Religion had been extensively studied and became the subject of various researches (Hood et al. 2009; Gorsuch 2002; James 2010; Geels 2003). William James, the eminent U.S. philosopher and one of the founders of the field of psychology of religion (Hood et al. 2009), admitted that he is "neither a theologian, nor a scholar learned in the history of religions, nor an anthropologist" (James 1917, p. 6). However, this did not prevent him from studying "religious propensities and their philosophic significance" (James 1917, p. 6). As a psychologist, William James asserts that the religious field is divided into "institutional" and "personal" wherein the former "keeps the divinity" while the latter "keeps man most in view" (James 1917, p. 30). Personal religion, which can also be referred to as "conscience or morality", refers to "the feelings, acts, and experiences of individual men in their solitude, so far as they apprehend themselves to stand in relation to whatever they may consider the divine" (James 1917, pp. 31-32). It is from the relationship of man with the divine (whether be it moral physical, or ritual) that "theologies, philosophies, and ecclesiastical organizations [or institutional religion] may secondarily grow" (James 1917, p. 32) Furthermore, for institutional religion, the essentials are, "worship and sacrifice, procedures for working on the dispositions of the deity, theology, and ceremony and ecclesiastical organization" (James 1917, p. 30).

How does the Catholic religion measure up to William James' definition of institutional religion? For Catholics, "Christianity is the religion of the Word of God", a word which is not a written and mute word, but the incarnate Word and living" (Catechism of the (Catholic Church 1997, para. 108)). It must be stressed however that Catholics are not simply defined as "people of the book". They are followers of the incarnate "Word of God" which is Jesus Christ. This personal relationship (moral, 
physical and spiritual) with Jesus Christ (the divine) is the source of the Christian life. Those who believe in the Catholic faith are incorporated into the Church through the sacrament of baptism and become sharers in the mission (Catechism of the (Catholic Church 1997, para. 1213)). Furthermore, the Christian faithful are composed of the religious (clerics, nuns and other consecrated persons) as well as the laity (Catechism of the (Catholic Church 1997, para. 934)). Those who aspire for the consecrated life must go through religious formation so that the candidates or novices will be able "to assimilate and deepen that in which religious identity consists" (Congregation for Institutes of Consecrated Life and Societies of Apostolic Life 1990, para. 6). This paper explores the personal religion, sociality and spiritual well-being of religious novices in an ecclesiastical organization (i.e., the Catholic Church) as they go through the religious formation process.

This paper also stresses that separating "institutional religion" with "personal religion" does not mean that individual religious experiences cannot collectively constitute a religious body of work. In The Varieties of Religious Experience: A Study in Human Nature, James (1917) admits this phenomenon when he asked, "Under just what biographic conditions did the sacred writers bring forth their various contributions to the holy volume? [i.e., The Bible] And what had they exactly in their several individual minds, when they delivered their utterances?" (p. 8)

Hence, while individual persons who relate with the divine gain a religious experience (James 2010, p. 34), among Catholics, such personal experiences with the divine (i.e., the incarnate and living Word of God Jesus Christ) are shared and lived with the other members of the Church (i.e., the baptized). Among the baptized Catholics, some aspire to the consecrated life. To assimilate and deepen such a religious identity (as a consecrated Catholic person), they must go through religious formation which calls for an integrative model composed of the personal, communal, environmental and transcendental domains.

James' 1917 assertion that "out of [personal] religion that theologies, philosophies, and ecclesiastical organizations secondarily grow" is observed in the Philippines. Before the arrival of the Spanish Catholic missionaries on the Philippine archipelago in the year 1521, the indigenous people already had a worldview and religion of their own. Despite this and other constraints, the Catholic Church took root in the Philippines and became the dominant religion (Del Castillo 2018, p. 3). In recent years, the Philippine Statistics Authority (2017) reported that 79.5 percent are Roman Catholics. This equates to almost four-fifths of the total population of the country.

With such a large number of the laity (those who are baptized yet do not belong to the holy orders or in a state of consecrated life specially approved by the Catholic Church) in the Philippines, religious formation houses must be established and novices receive religious formation towards becoming Catholic ministersCatholic Church (1997) directs the formation in religious institutes, saying:

Major superiors, and those responsible for formation, should know that current circumstances, now more than ever, require conditions of stability sufficient to enable the novices to grow and advance in the spirit profoundly and peacefully. [ ... ] Novices need to be trained in the practice of prolonged prayer, solitude, and silence. For all this, the element of time plays a determining role. They can have a greater need "to withdraw" from the world than "to go" to the world, and this need is not merely subjective. This is why the time and place of the novitiate will be organized so that the novices can find an atmosphere that is favorable to become deeply rooted in a life with Christ. But this is only achieved by becoming detached from oneself, from all that which opposes God in the world, and even from those goods of the world that undoubtedly deserve to be highly valued. (Congregation for Institutes of Consecrated Life and Societies of Apostolic Life 1990, para 50)

\section{The Novitiate as a Religious Experience}

Among the Catholic religious congregations, the Salesian Society of St Francis of Sales declares: 
"[The] novitiate is the beginning of the Salesian religious experience in following Christ. Its purpose is to give the novices a greater understanding of their divine vocation, and of their vocation to that institute. During the novitiate, the novices are to experience the manner of life of the Institute and form their minds and hearts in its spirit. At the same time, their resolution and suitability are to be tested. In this phase, with the help of the director of novices and the community, the novice learns to live the Salesian apostolic consecrated life more directly as a religious experience: he deepens the motivations for his choice, acquires a faith mentality and assimilates Salesian values." (Direzione Generale Opere Don Bosco 2016, para. 357)

Thus, the Catholic novitiate is both a religious experience in following Christ and a deepening of spiritual life. The novices under the formation program should progress "in light of the fruits of the Spirit" (Congregation for Institutes of Consecrated Life and Societies of Apostolic Life 1990, para. 30). Interestingly, James (1917) explained that "the sense of Presence of a higher and friendly Power seems to be the fundamental feature in the spiritual life" and that "in the Christian consciousness this sense of the enveloping friendliness becomes most personal and definite" (p. 269). This observation is congruent with one of the ideals in the formation of novices wherein they should "be detached from themselves and grow and advance in the spirit [i.e., the Divine, higher and friendly Power, or God] profoundly and peacefully" (Congregation for Institutes of Consecrated Life and Societies of Apostolic Life 1990, para. 30).

Ideally, Catholic novices should "build a community of brothers or sisters in Christ where each one, aware of his or her responsibility within the community, is moved to grow, not only for self but for the good of all" (Congregation for Institutes of Consecrated Life and Societies of Apostolic Life 1990, para. 27). James (1917) described community building that is anchored upon charity and brotherly love as another fruit of saintliness. He asserts, "brotherly love would follow logically from the assurance of God's friendly presence, the notion of our brotherhood as men being an immediate inference from that of God's fatherhood of us all (James 1917, p. 273)

Moreover, Catholic novices should have ample time and a conducive place for solitude and silence so that they may hear and assimilate the Word of God. These "favor the spiritual maturation of the person and a true fraternal communion in Christ" (Congregation for Institutes of Consecrated Life and Societies of Apostolic Life 1990, para. 38). Such an ideal environment reflects James (1917) made the observation that equanimity, resignation, fortitude and patience are aroused by the faith-state. He says, “'A paradise of inward tranquility' seems to be faith's usual result" (James 1917, p. 279).

Another ideal for the formation of novices is the "cultivation of human and Christian virtues. [They] are to be introduced to a fuller way of perfection by prayer and self-denial [ ... ]" (Congregation for Institutes of Consecrated Life and Societies of Apostolic Life 1990, para. 46). Such "perfection" reflects James' (1917) observation of a religious symptom called "purity of life" wherein "the saintly person becomes exceedingly sensitive to inner inconsistency or discord, and mixture and confusion grow intolerable. [ ... ] Mixed with this exaltation of the moral sensibilities there is also an ardor of sacrifice, for the beloved deity's sake, of everything unworthy of him" (James 1917, p. 285).

Reconciling the definition of personal religion and gleaning the fruits of spiritual life explained by James (1917) as well as the constructs used to describe the formation in religious institutes (i.e., novitiate) we realize that indeed, the Catholic novices who are "withdrawn from the world and trained in the practice of prolonged prayer, solitude, and silence to become deeply rooted in a life with Christ" (Congregation for Institutes of Consecrated Life and Societies of Apostolic Life 1990, para. 50) do "feel, act, experience, and apprehend themselves to stand in relation to the divine" (James 2010, p. 34).

The religious experience shape and influence the sociality of the Catholic novices. Hood et al. (2009) describe sociality as "the behaviors that relate organisms to one another, and that keeps an individual identified with a group. Included here are expressions of social support, cooperation, adherence to group standards, attachment to others, altruism, and many other actions that maintain 
effectively functioning groups. Faith systems accomplish these goals for many people, and in return, the cultural order embraces religion" (p. 19).

Only by relating well with the other participants (and stakeholders) of the formation program will the novices thrive and find purpose in their vocation. Indeed, "it is through others that a sense of meaning is often most fully experienced" (Hood et al. 2009, p. 13). Furthermore, the formation in religious institutes aims to develop the spiritual health of the novices. Fisher (2011) explains that "spiritual health is a dynamic state of being, reflected in the quality of relationships that people have in up to four domains of spiritual well-being: Personal domain where a person intra-relates with self; Communal domain, with in-depth inter-personal relationships; Environmental domain, connecting with nature; Transcendental domain, relating to some-thing or some-One beyond the human level". (Fisher 2011, p. 19)

Table 1 shows the intimate link between the domains of spiritual well-being and the ideals of the formation program of novices:

Table 1. Domains and Items of Spiritual Well-Being and Ideals for Formation of Novices.

\begin{tabular}{|c|c|}
\hline $\begin{array}{l}\text { Domains and Items of Spiritual } \\
\text { Well-Being }\end{array}$ & Ideals for Formation of Novices \\
\hline $\begin{array}{l}\quad \text { Personal domain } \\
\text { 1. Love of other people } \\
\text { 2. Personal relationship with the } \\
\text { Divine/God } \\
\text { 3. Forgiveness toward other } \\
\text { 4. Connection with nature } \\
\text { 5. A sense of identity }\end{array}$ & $\begin{array}{l}\text { Novices must be detached from themselves. They should grow and } \\
\text { advance in the spirit profoundly and peacefully (Congregation for } \\
\text { Institutes of Consecrated Life and Societies of Apostolic Life 1990, } \\
\text { para. 50). }\end{array}$ \\
\hline $\begin{array}{l}\text { Communal domain } \\
\text { 6. Worship of the Creator } \\
\text { 7. Awe at a breathtaking view } \\
\text { 8. Trust between individuals } \\
\text { 9. Self-awareness } \\
\text { 10. Oneness with nature }\end{array}$ & $\begin{array}{l}\text { Novices must build a community of brothers or sisters in Christ. } \\
\text { Then, each one, aware of his or her responsibility within the } \\
\text { community, is moved to grow, not only for self but for the good of all } \\
\text { (Congregation for Institutes of Consecrated Life and Societies of } \\
\text { Apostolic Life 1990, para. 27). }\end{array}$ \\
\hline $\begin{array}{l}\text { Environmental domain } \\
\text { 11. Oneness with God } \\
\text { 12. Harmony with the environment } \\
\text { 13. Peace with God } \\
\text { 14. Joy in life } \\
\text { 15. Prayer life }\end{array}$ & $\begin{array}{l}\text { The regulation of every religious community, not only of houses of } \\
\text { formation, should provide for times and places of solitude and } \\
\text { silence; these foster hearing and assimilating the word of God, and } \\
\text { at the same time, favor the spiritual maturation of the person and a } \\
\text { true fraternal communion in Christ (Congregation for Institutes of } \\
\text { Consecrated Life and Societies of Apostolic Life 1990, para. 38). }\end{array}$ \\
\hline $\begin{array}{l}\quad \text { Transcendental domain } \\
\text { 16. Inner peace } \\
\text { 17. Respect for others } \\
\text { 18. Meaning in life } \\
\text { 19. Kindness towards other people } \\
\text { 20. A sense of 'magic' in the environment }\end{array}$ & $\begin{array}{l}\text { The practice of prolonged prayer, of solitude, and silence } \\
\text { (Congregation for Institutes of Consecrated Life and Societies of } \\
\text { Apostolic Life 1990, para. 50) }\end{array}$ \\
\hline
\end{tabular}

The period of religious formation is critical if the novices hope to follow Christ according to the radicalism of their consecration (Congregation for Institutes of Consecrated Life and Societies of Apostolic Life 1990, para. 27). This radicalism is demonstrated when a Christian "affirms the dignity of every person as a child of God, establishes a basic fraternity, teaches people to encounter nature and understand work, [and] provides reasons for joy and humor even amid a very hard life" (Catechism of the (Catholic Church 1997, para. 1676)). With such lofty ideals, one is led to ask, "How does the formation of religious Catholic novices affect their sociality, specifically on the four domains?" and "What is their spiritual health?" Hence, there is a need to compare the lived experience of religious novices with ideals to better measure the quality of their relationships. These objectives were attained by using the Spiritual Health and Life-Orientation Measure (SHALOM) developed by Fisher (2011) 
which shed light on the quality of relationships of each religious novice with themselves, other people, the environment and God.

\section{Materials and Methods}

The study took a convenience sample of 50 religious novices from different religious congregations in the Philippines. The respondent's demographic profiles were categorized by gender, age and nationality. Among the respondents, there were 22 males and 28 females. The youngest respondent was 21 years old while the oldest was 37 years old. All participants were duly informed of their privacy and the confidentiality of the results. According to nationality, 30 were natural-born Filipinos while 20 were foreigners who were sent to the Philippines for religious formation. The researcher utilized the Spiritual Health and Life Orientation Measure (SHALOM) of Fisher (2011) as a research instrument. The SHALOM asked the respondents to give two responses to each of the 20 items to show (1) how important the domains of spiritual well-being are for their ideal state of spiritual health and (2) how the respondents felt that each item reflects their personal experience most of the time. The responses of the religious novices were analyzed to determine their "congruence level of harmony" (spiritual well-being) on the four domains: (1) personal spiritual well-being, (2) communal spiritual well-being, (3) environmental spiritual well-being and (4) transcendental spiritual well-being. The respondents evaluated the importance of the domains of spiritual well-being for their ideal state of spiritual health (or ideals) and how each item reflects their personal experience most of the time (feelings) using a 5 -point Likert scale $(1=$ "very low to $5=$ "very high"). After this, the results were quantitatively analyzed using the weighted mean. Using objective data, the scores which showed their ideal for spiritual health were compared with their scores on the items regarding their feelings.

\section{Results}

The results showed that there was a significant difference between the ideals of the religious novices and how they truly felt. There was spiritual dissonance between the spiritual well-being of the novices and their lived experience. The congruence level of harmony between ideals and spiritual health of the novices leads one to inquire if they are truly thriving in their religious formation and more importantly if such experience provides them with purpose and meaning.

Table 2 shows the importance of the domains of spiritual well-being in attaining an ideal state of spiritual health. The Catholic novices strongly agree and were homogenous (coefficient of variation $(C V)=14 \%$ ) on "personal spiritual well-being as necessary for one's spiritual health" (mean $(M)=21.88$, standard deviation $(\mathrm{SD})=3.07)$. The respondents recognized that identity, self-awareness, joy in life, inner peace and sense of purpose are all necessary for the pursuit of the meaning of life. They were also in strong agreement that inter-personal relations in the community are important for spiritual well-being $(\mathrm{M}=21.30, \mathrm{SD}=3.32)$. Inter-personal relations are demonstrated in acts of forgiveness, love, and promoting justice. Since the respondents came from various religious congregations with different charisms and spirituality, they were understandably heterogenous in their responses $(C V=15.59 \%)$. In the environment domain, the respondents strongly agreed that connectedness with nature and a sense of awe and wonder in creation is important for spiritual health $(\mathrm{M}=22.80, \mathrm{SD}=2.13)$. Indeed, a "favorable atmosphere" is necessary if one desires to be deeply rooted in a life with Christ (Congregation for Institutes of Consecrated Life and Societies of Apostolic Life 1990, para. 50). Lastly, the respondents strongly agreed (and were homogenous in their response) that transcendental spiritual well-being is very important for spiritual health $(\mathrm{M}=21.60, \mathrm{SD}=3.18)$. They recognized the necessity of prolonged prayer, solitude and silence to advance the spirit profoundly and peacefully. 
Table 2. Results of the ideals for spiritual health survey.

\begin{tabular}{ccccccc}
\hline Ideals & $\begin{array}{c}\text { Minimum } \\
\text { Score }\end{array}$ & $\begin{array}{c}\text { Maximum } \\
\text { Score }\end{array}$ & Mean & $\begin{array}{c}\text { Standard } \\
\text { Deviation }\end{array}$ & $\begin{array}{c}\text { Coefficient } \\
\text { of Variation }\end{array}$ & Description \\
\hline $\begin{array}{c}\text { Personal } \\
\text { Domain }\end{array}$ & 10 & 25 & 21.88 & 3.07 & $14 \%$ & $\begin{array}{c}\text { Strongly } \\
\text { agree/homogenous }\end{array}$ \\
\hline $\begin{array}{c}\text { Communal } \\
\text { Domain }\end{array}$ & 10 & 25 & 21.30 & 3.32 & $15.59 \%$ & $\begin{array}{c}\text { Strongly } \\
\text { agree/heterogeneous }\end{array}$ \\
\hline $\begin{array}{c}\text { Environmental } \\
\text { Domain }\end{array}$ & 16 & 25 & 22.80 & 2.13 & $9.34 \%$ & $\begin{array}{c}\text { Strongly } \\
\text { agree/homogeneous }\end{array}$ \\
\hline $\begin{array}{c}\text { Transcendental } \\
\text { Domain }\end{array}$ & 8 & 25 & 21.60 & 3.18 & $14.72 \%$ & $\begin{array}{c}\text { Strongly } \\
\text { agree/homogeneous }\end{array}$ \\
\hline
\end{tabular}

Table 3 shows how the Catholic novices felt that each item (in SHALOM) reflected their personal experience. The respondents moderately agreed that they feel a sense of personal well-being $(M=20.48$, $\mathrm{SD}=2.56)$. They also had a homogenous response $(\mathrm{CV}=12.5 \%)$ which indicates that they generally felt the same way. Concerning the communal domain, the respondents moderately agreed that they feel a sense of community as they go through the religious formation. This shows that they feel trusted, valued, and when necessary, forgiven by the other novices and stakeholders of the formation program. As to the environmental domain, the respondents strongly agreed $(\mathrm{M}=21.40, \mathrm{SD}=2.39)$ and were homogenous $(\mathrm{CV}=11.17 \%)$ in saying that they experience and feel a sense of well-being through nature and the environment. Lastly, the Catholic novices moderately agreed $(\mathrm{M}=20.20, \mathrm{SD}=3.09)$ and were homogeneous ( $\mathrm{CV}=15.29 \%)$ in having a personal connection with God. This indicates that the experience of prolonged prayer, solitude, and silence has given them opportunities to relate to the divine.

Table 3. Results of the feelings survey.

\begin{tabular}{ccccccc}
\hline Feelings & $\begin{array}{c}\text { Minimum } \\
\text { Score }\end{array}$ & $\begin{array}{c}\text { Maximum } \\
\text { Score }\end{array}$ & Mean & $\begin{array}{c}\text { Standard } \\
\text { Deviation }\end{array}$ & $\begin{array}{c}\text { Coefficient } \\
\text { of Variation }\end{array}$ & Description \\
\hline $\begin{array}{c}\text { Personal } \\
\text { Domain }\end{array}$ & 15 & 25 & 20.48 & 2.56 & $12.5 \%$ & $\begin{array}{c}\text { Moderately } \\
\text { agree/homogenous }\end{array}$ \\
\hline $\begin{array}{c}\text { Communal } \\
\text { Domain }\end{array}$ & 12 & 25 & 20.08 & 2.94 & $14.64 \%$ & $\begin{array}{c}\text { Moderately } \\
\text { agree/heterogeneous }\end{array}$ \\
\hline $\begin{array}{c}\text { Environmental } \\
\text { Domain }\end{array}$ & 15 & 25 & 21.40 & 2.39 & $11.17 \%$ & $\begin{array}{c}\text { Strongly } \\
\text { agree/homogeneous }\end{array}$ \\
\hline $\begin{array}{c}\text { Transcendental } \\
\text { Domain }\end{array}$ & 12 & 25 & 20.20 & 3.09 & $15.29 \%$ & $\begin{array}{c}\text { Moderately } \\
\text { agree/homogeneous }\end{array}$ \\
\hline & & Valid N (listwise) 50 & & \\
\hline
\end{tabular}

Table 4 compares the responses of the Catholic novices between their ideals of spiritual well-being and how they truly felt or experienced it. Between the "ideal personal domain" and "feelings (or experiences) on the personal domain", the scores showed $t=21.88, d f=49$, with 0.002 levels of significance. This indicates that responses to the variables are significantly different from each other. This means, in the personal realm, that the ideals for the spiritual health of the Catholic novices are incongruent to what they feel or experience. Comparing the "ideal communal domain" and "feelings (or experiences) on the communal domain", the scores showed $t=3.33, d f=49$ with 0.002 levels of significance. This reveals that there is a lack of congruence between the ideals of a community as perceived by the Catholic novices and their actual relationships with other people who are also in the process of religious formation. The scores between "ideal environmental domain" and "feelings (or experiences) on the environmental domain" are $t=4.25, d f=49$ with 0.000 level of significance. This points to a lack of congruence harmony between their ideals of being one with nature or being awestruck by the environment and their personal lived experience. Lastly, the scores between "ideal 
transcendental domain" and "feelings (or experiences) on the transcendental domain" showed $t=3.51$, $d f=49$ with 0.001 level of significance. This reveals that their ideal of a relationship with the divine is different from what they felt and experienced.

Table 4. Results of comparison between ideals and feelings.

\begin{tabular}{|c|c|c|c|c|c|c|}
\hline $\begin{array}{c}\text { Paired } \\
\text { Variables }\end{array}$ & $\begin{array}{l}\text { Highest } \\
\text { Score }\end{array}$ & $\begin{array}{l}\text { Lowest } \\
\text { Score }\end{array}$ & Mean & $t$ & Sig. & Description \\
\hline $\begin{array}{c}\text { Ideal } \\
\text { Personal and } \\
\text { Feelings } \\
\text { Personal }\end{array}$ & 25 & $\begin{array}{l}\mathrm{L}_{1}=10 \\
\mathrm{~L}_{2}=15\end{array}$ & $\begin{array}{l}\mathrm{m}_{1}=21.88 \\
\mathrm{~m}_{2}=20.48\end{array}$ & 21.88 & 0.002 & $\begin{array}{c}\text { Significantly } \\
\text { Different }\end{array}$ \\
\hline $\begin{array}{c}\text { Ideal } \\
\text { Communal } \\
\text { and Feelings } \\
\text { Communal }\end{array}$ & 25 & $\begin{array}{l}\mathrm{L}_{1}=10 \\
\mathrm{~L}_{2}=12\end{array}$ & $\begin{array}{l}\mathrm{m}_{1}=21.30 \\
\mathrm{~m}_{2}=20.08\end{array}$ & 3.33 & 0.002 & $\begin{array}{c}\text { Significantly } \\
\text { Different }\end{array}$ \\
\hline $\begin{array}{l}\text { Ideal } \\
\text { Environmental } \\
\text { \& Feelings } \\
\text { Environmental }\end{array}$ & 25 & $\begin{array}{l}\mathrm{L}_{1}=16 \\
\mathrm{~L}_{2}=15\end{array}$ & $\begin{array}{l}\mathrm{m}_{1}=22.80 \\
\mathrm{~m}_{2}=21.40\end{array}$ & 4.25 & 0.000 & $\begin{array}{c}\text { Significantly } \\
\text { Different }\end{array}$ \\
\hline $\begin{array}{l}\text { Ideal } \\
\text { Transcendental } \\
\text { \& Feelings } \\
\text { Transcendental }\end{array}$ & 25 & $\begin{array}{c}\mathrm{L}_{1}=8 \\
\mathrm{~L}_{2}=12\end{array}$ & $\begin{array}{l}\mathrm{m}_{1}=21.60 \\
\mathrm{~m}_{2}=20.20\end{array}$ & 3.51 & 0.001 & $\begin{array}{c}\text { Significantly } \\
\text { Different }\end{array}$ \\
\hline
\end{tabular}

\section{Discussion}

The survey revealed that the formation of religious Catholic novices affects their sociality. While the novices are "withdrawn from the world" during the period of religious formation, their religious experience becomes meaningful only when they are able "to go" to the world again and share the spirit that they have come to discover profoundly and peacefully. The Catholic novices are acutely aware of the ideals that lead to spiritual well-being, namely the quality of relationships their relationship with themselves (intra-personal), other people (inter-personal), the environment (communal) and God (transcendental). These domains largely fall under sociality where an individual's sense of meaning and purpose are fully experienced with others. However, the cognition of ideals is only a part of spiritual health. The Catholic novices must experience the reality of such ideals and whenever possible put them into practice. When the variables of "ideals" and "feelings" were paired, the results showed that the Catholic novices experience spiritual dissonance.

Analyzing the paired variables with the highest mean (i.e., environmental), the researchers infer that the spiritual health of the Catholic novices benefit from an environment or formation house that is conducive for prolonged prayer, solitude and silence as they discover and nurture a relationship with the divine. In the Philippines, numerous formation houses are situated on a hill, mountain top or plateau. The cold temperature due to the high elevation as well as seclusion provides the body and mind with suitable conditions for introspection and communion with God. As for the paired variables with the lowest mean (i.e., communal), we infer that living in a community (i.e., with other Catholic novices undergoing formation) is a challenge. Since the novices live together in a formation house (or community), there will be times that the different personalities and characters will clash and cause some harm to one's spiritual well-being.

\section{Conclusions}

Using the Spiritual Health and Life-Orientation Measure (SHALOM) developed by Fisher (2011), this paper was able to establish by standard scientific methods that (1) the formation (or religious experience) of religious Catholic novices does affect their sociality and that (2) the Catholic novices, 
while keenly aware of the ideals of spiritual health, experience spiritual dissonance in terms of experiencing and feeling such ideals. As a recommendation, the researchers encourage the directors of religious formation to integrate the four dimensions of spiritual well-being (with emphasis on the communal domain) in the period of formation (or religious experience) of the novices to improve their spiritual health.

Author Contributions: Conceptualization, F.d.C., M.A., and C.D.d.C.; Methodology, F.d.C. and M.A.; Software, M.A.; Validation, M.A. and F.d.C.; Formal Analysis, F.d.C., M.A., and C.D.d.C.; Investigation, F.d.C., M.A., and C.D.d.C.; Resources, F.d.C., M.A., and C.D.d.C.; Data Curation, M.A.; Writing-F.d.C., M.A., and C.D.d.C.; Writing-Review \& Editing, F.d.C., M.A., and C.D.d.C.; Visualization, F.d.C.; Supervision, F.d.C.; Project Administration, F.d.C. All authors have read and agreed to the published version of the manuscript.

Funding: This research received no external funding.

Conflicts of Interest: The authors declare no conflict of interest.

\section{References}

Catholic Church. 1997. Catechism of the Catholic Church, 2nd ed. Vatican City: Libreria Editrice Vaticana.

Congregation for Institutes of Consecrated Life and Societies of Apostolic Life. 1990. Directives on Formation in Religious Institutes. Available online: https://www.vatican.va/roman_curia/congregations/ccscrlife/ documents/rc_con_ccscrlife_doc_02021990_directives-on-formation_en.html (accessed on 15 May 2020).

Del Castillo, Fides. 2018. Perspectives on faith and culture in the Philippines, East Timor, and Indonesia. The International Journal of Civic, Political, and Community Studies 16: 1-11. [CrossRef]

Direzione Generale Opere Don Bosco. 2016. Formation of Salesians of Don Bosco, Online ed. Available online: https://formazionesdborg.files.wordpress.com/2016/12/ratio_2016_en.pdf (accessed on 15 May 2020).

Fisher, John. 2011. The Four Domains Model: Connecting Spirituality, Health, and Well-Being. Religions 2: 17-28. [CrossRef]

Geels, Antoon. 2003. Transforming moments. A psychological perspective on religious visions: Contemporary and historical cases. In Mysticism. A Variety of Psychological Perspectives. Edited by Jacob A. Belzen and Antoon Geels. New York: Rodopi.

Gorsuch, Richard L. 2002. Integrating Psychology and Spirituality. Westport: Praeger.

Hood, Ralph, Peter C. Hill, and Bernard Spilka. 2009. Psychology of Religion, 4th ed. New York: Guilford Press.

James, William. 2010. The Varieties of Religious Experience: A Study in Human Nature. New York: Classic Books International. First published 1902.

James, William. 1917. The Varieties of Religious Experience: A Study in Human Nature. Being the Gifford Lectures on Natural Religion. New York: Longmans, Green and Co.

Philippine Statistics Authority. 2017. Results from the 2015 Census of Population. Available online: https: //psa.gov.ph/population-and-housing/node/120080 (accessed on 15 May 2020). 